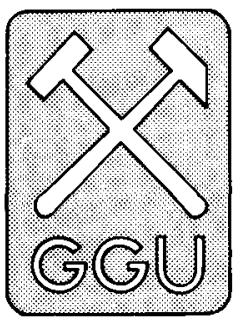

\title{
GGU's photogeological laboratory: aerial photogrammetry - a valuable geological mapping tool in Greenland
}

\author{
Grethe Hougaard, Hans F. Jepsen and \\ Jørgen K. Neve
}

Geological mapping in Greenland is generally greatly helped by the use of vertical aerial photographs. Bedrock surfaces are normally well exposed, vegetation is sparse in most parts of the country and glacial deposits can be scattered or completely washed away. Consequently, geological features such as bedding, stratigraphical boundaries and large-scale structures are commonly visible on aerial photographs.

Since its establishment in 1946 as an independent institution, the Geological Survey of Greenland (GGU) has made extensive use of aerial photographs during mapping campaigns, and photogeological interpretation has played an important role in Copenhagen during map compilation.

\section{Establishment of a photogeological laboratory at GGU}

Many GGU geologists commonly use aerial photographs as base maps onto which field stations and geological information are plotted directly. In Copenhagen, these annotated photographs are further interpreted; important stratigraphic boundaries may be extrapolated into areas lacking field observations, and structures can often be elucidated taking advantage of the three-dimensional view offered by the stereoscope. Finally the details shown on the photographs are transferred onto topographic maps, which then constitute the raw material for the production of the different types of standard map sheets described by Dawes (1990).

The technique as described has several drawbacks, particularly in the interpretation of the annotated fieldphotographs and transference of the detail to topographic maps. For many years, pocket stereoscopes or table-mounted mirror stereoscopes were used for interpretation purposes, but they offered limited and inaccurate possibilities for measuring geological parameters such as bed position or thickness. Transference of results to a topographic map was done manually by visual comparison or by using a sketchmaster instrument making it possible optically to superimpose the photographic image onto the map. A matter of further concern is the quality of the topographic base maps covering Greenland, because in many areas their resolution is too low for precise localisation of geological data. Furthermore, in North Greenland where GGU was planning a regional mapping campaign to be initiated in 1978, the existing topographic maps were totally inadequate for representation of detailed geological documentation (Dawes, 1987).

In order to overcome these problems it was decided in 1975 to examine the feasibility of using modern and precise photogrammetric methods during the geological interpretation of aerial photographs. Also, the cost and manpower involved in producing more accurate topographic base maps was examined. In co-operation with the Institute of Surveying and Photogrammetry, Technical University of Denmark, several pilot projects were initiated (Dueholm, 1976, 1979; Dueholm et al., 1977; Dawes, 1977, 1979, 1987; Jepsen \& Dueholm, 1978) and based on the experience gathered it was concluded in 1977 that GGU should establish a laboratory for geologically applied photogrammetry.

The laboratory was equipped with a high-precision, digital stereorestitution instrument (Kern PG2 stereoplotter), an automatic flat-bed plotter and a real-time Hewlett-Packard minicomputer (HP1000). A full-time technician was employed and trained as operator. Software for process control and for calculation of geological parameters was developed in-house (H. F. J.) and in co-operation with experts from the Institute of Surveying and Photogrammetry and from the Geodetic Institute, Copenhagen.

\section{Methods}

After an initial period of system and software development, the laboratory now offers a varied selection of routine procedures covering different aspects of map compilation, and since 1979 many geological maps published by GGU have been compiled using the equipment installed in the laborarory.

The compilation system (the GGU PG2-system) handles the following procedures: 
- Compilation of topographic maps including preceeding aerotriangulation, if necessary.

- Transference of geological features from photographs to map.

- Measurement of planar structures, true thickness of structural units, vertical displacement along faults, plunge and direction of fold axes etc.

- Interpolation and extrapolation of planar structures or marker horizons.

In addition, on-demand software development is possible when unique geological aspects need special treatment.

A prerequisite for systematic photogeological map compilation is the existence of complete coverage of the area with good quality vertical photographs and $x y z-$ coordinated ground control points. Fortunately, the Kort- og Matrikelstyrelsen (KMS) of Denmark (formerly the Geodetic Institute) has continuously promoted aerial photography and field work in Greenland, and today the whole ice-free land area $\left(459600 \mathrm{~km}^{2}\right)$ is covered by vertical photographs at scales of 1:50 000 and 1:150 000 . Ground control points are available for most of the country and these points can be expanded to cover each individual photograph via the process of aerotriangulation. The KMS and GGU's laboratory have between them carried out aerotriangulation of photographs covering approximately 40 per cent of the ice-free land area.

After the preparation of photographs and corresponding ground control points a geological compilation project can be initiated. It typically involves both the technical operator (J. K. N.) and a geologist. A pair of photographs (a stereomodel) is mounted in the PG2 stereoplotter and oriented according to ground control points marked either on the photographs themselves or on the corresponding map. If the existing base map does not have sufficient resolution, the operator draws out a new base map showing the main topographic elements including contour lines (Fig. 1A).

During the geological compilation the geologist combines all available field observations with interpretation data extracted from the stereomodel and the result is transferred to the map (Fig. 1B). Geological parameters may be measured; the orientation of bedding or foliation can be calculated and dip-strike symbols automatically plotted on the map, thicknesses of lithological units may be measured, and where possible marker horizons can be extended between field stations or extrapolated into areas with superficial cover.

A preliminary geological compilation of a target area can also be completed before the area is visited in the field, and in this way areas of special interest may be
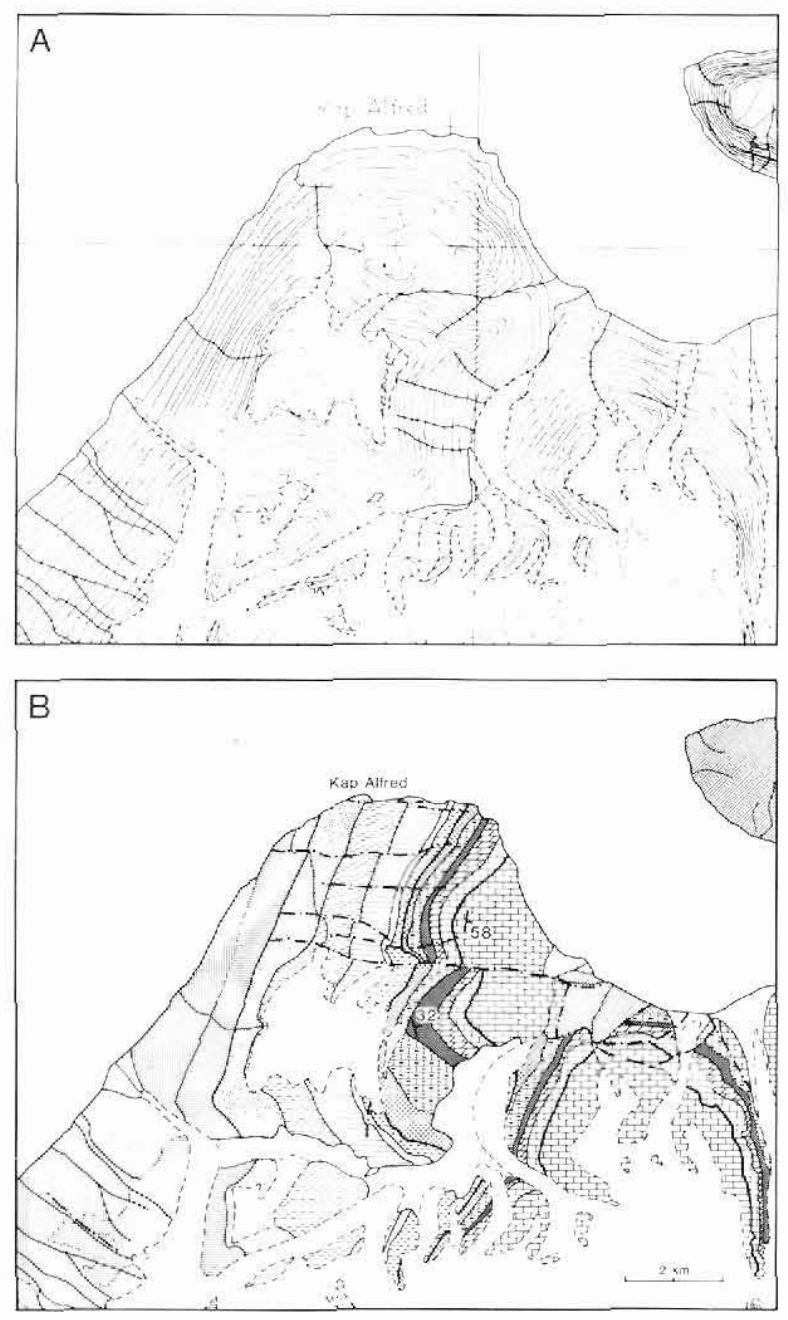

Fig. 1. (A) Example of a topographic map produced by the PG2-system. Contour interval is $100 \mathrm{~m}$. Kap Alfred, Lyell Land, East Greenland. (B) Geological map of the same area compiled using the PG2-system.

defined prior to the field campaign. By using this approach it is often possible to increase the efficiency of the subsequent field work, and also to reduce the amount of costly helicopter support.

Besides being plotted directly on the map, all lines and symbols are stored on magnetic tapes as digital $x y z$-point data. Off-line plotting from this database is carried out as a routine procedure. It is thus possible to produce maps at any chosen scale, and to produce scribed versions of topographic line maps, which, after cartographic editing (G. H.) are suitable for reproduction.

The digital point data can be used for three-dimensional modelling or the data can be combined with 


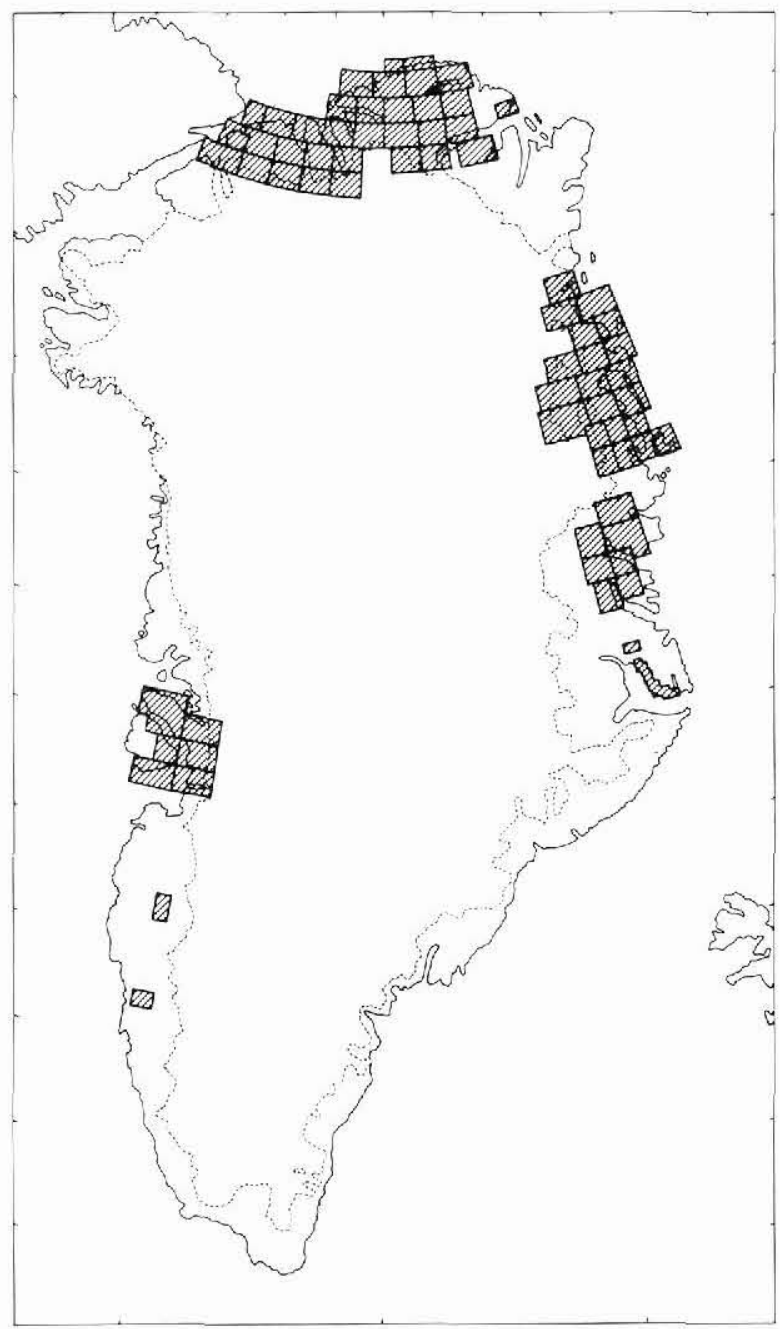

Fig. 2. Index map showing the distribution of geological and topographic maps produced by GGU's photogeological laboratory. Most of the maps are at scale 1:100 000.

digital data from other sources, such as gravimetric measurements.

\section{Status and geological mapping experience}

Up to the present a total of 140 topographical maps covering approximately $20 \mathrm{per}$ cent $\left(100000 \mathrm{~km}^{2}\right)$ of Greenland's ice-free land area have been produced in GGU's photogeological laboratory (Fig. 2). Most maps are at a scale of 1:100 000 and were compiled in connection with GGU's regional mapping campaigns in North Greenland (1978-80 and 1984-85), in North-East Greenland (1986-90) and in central West Greenland (1987-89). The topographic maps and the geological interpretation and compilation covering these regions were based on aerial photographs at a scale of 1:150000.

\section{Regional mapping}

The Proterozoic and Phanerozoic sedimentary basins in North Greenland and in North-East Greenland are very well exposed. They are composed of a succession of variable lithologies, many of which stand out as characteristic photogenic distinct marker units and horizons. It was possible to compile consistent geological maps covering large parts of these areas based on sparse geological reconnaissance data gathered prior to the start of the main mapping campaigns.

In addition, a great deal of structural information has been extracted from aerial photographs covering the North Greenland fold belt, which is composed of intensely deformed Proterozoic and Palaeozoic sequences. Dip-strike measurements and trend lines depicting the main structures were transferred to the map, although in such areas field work was essential to provide the detailed understanding necessary for the final map compilation.

The Tertiary plateau basalts in central West Greenland are also well suited for photogeological interpretation work; the lava pile is stratiform and virtually undeformed and thus lateral correlation of lava flows can often be established using aerial photographs.

Large parts of central West Greenland and NorthEast Greenland are composed of crystalline basement of Archaean and Proterozoic ages. The 1:150 000 photographs covering these areas have yielded only limited geological information. The colour contrasts between different lithologies are normally very weak and only distinct marker units such as amphibolite bodies or banded greenstone units can be defined on the photographs.

\section{Specialised mapping}

Concurrently with regional mapping projects more detailed or specialised compilation work has been carried out in the photogeological laboratory; areas in West Greenland, South-West Greenland and South Greenland have been examined in detail. These areas are composed of Archaean and Proterozoic crystalline rocks, and as noted above photogeological interpretation work in such areas may be hampered by the lack of good marker horizons. In order to obtain maximum resolution, photographs at scales of 1:40 000 or 1:50 000 have usually been used for the interpretation work.

Two examples of detailed compilation work are briefly described here. 
Extensive field work in the area between Fiskefjord, Taserssuaq and Godthåbsfjord was followed up by a map compilation project carried out in the laboratory. The results are two map sheets at scale 1:100 000 (Garde, 1987, 1989). About 80 vertical aerial photographs (1:40000) covering approximately 60 per cent of the area of the map sheets were examined and all field observations transferred to a draft map at scale 1:50 000. Limited additional geological data were added during this process; only lenses and bands of amphibolite could be extrapolated into areas not visited during the field season and few structural elements could be elucidated. The greatest advantage in using the stereoplotter during the compilation phase of the map sheets was the high precision with which the many detailed field observations could be transferred to the maps.

In connection with a glaciological programme carried out at the Pâkitsoq basin, central West Greenland, $x y z$ coordinated contour lines from the database were used in a three-dimensional modelling experiment. Ice-thickness data, obtained during an electromagnetic reflection survey, were subtracted from the contour line data and the result published as a subglacial relief map depicting the drainage system below the ice cap (Thorning \& Hansen, 1987).

Also, in a study of the glacial mass-balance of the Pâkitsoq area the change of the glacial surface relief over a period spanning 23 years was examined using several generations of aerial photographs (Thomsen $e t$ al., 1986). The change of ice-surface elevation was determined with a precision of $3 \mathrm{~m}$ and published as a contoured map.

\section{Future developments}

It has now been firmly established that the use of modern, high-precision photogrammetric methods in Greenland during geological map compilation is advantageous both from the point of view of productivity and quality of the resulting maps. Further development of the equipment and the controlling software will therefore be pursued in the coming years.

The intention is to develop software capable of dealing with curved or deformed surfaces and to implement a graphics editing utility in order to improve the cartographic capabilities of the system.

\section{References}

Dawes, P. R. 1977: Geological photo-interpretation of Hall Land: part of the regional topographical-geological mapping of northern Greenland. Rapp. Grønlands geol. Unders. 85, 25-30.

Dawes, P. R. 1979: Computer-supported photogrammetric, geological and topographic mapping of Hall Land, North Greenland. Meddr Inst. Landmåling og Fotogrammetri, Danm. Tekn. Højsk. 10, 147-170.

Dawes, P. R. 1987: Topographical and geological maps of Hall Land, North Greenland. Bull. Grønlands geol. Unders. 155, $88 \mathrm{pp}$.

Dawes, P. R. 1990: Geological mapping of Greenland. Rapp. Grønlands geol. Unders. 148, 10-15.

Dueholm, K. S. 1976: New instruments for geological photointerpretation and mapping. Rapp. Grønlands geol. Unders. 80, 144-148.

Dueholm, K. S. 1979: Geological and topographic mapping from aerial photographs. Meddr Inst. Landmåling og Fotogrammetri, Danm. Tekn. Højsk. 10, 9-146.

Dueholm, K. S, Pedersen, A. K. \& Ulff-Møller, F. 1977: High precision photogrammetric methods used in geological mapping. Rapp. Grønlands geol. Unders. 81, 53-56.

Garde, A. A. (compiler) 1987: Geological map of Greenland 1:100 000, Isukasia, 65 V.2 Syd. Copenhagen: Geological Survey of Greenland.

Garde, A. A. (compiler) 1989: Geological map of Greenland 1:100 000, Fiskefjord, 64 V.1 Nord. Copenhagen: Geological Survey of Greenland.

Jepsen, H. F. \& Dueholm, K. S. 1978: Computer supported geological photo-interpretation. Rapp. Grønlands geol. Unders. 90, 146-150.

Thomsen, H. H., Thorning, L. \& Braithwaite, R. 1986: Vurdering af de gletscher-hydrologiske forhold på Indlandsisen ved Paakitsup Akuliarusersua, Ilulissat/Jakobshavn. Unpubl. intern. GGU rep., 42 pp.

Thorning, L. \& Hansen, E. 1987: Electromagnetic reflection survey 1986 at the Inland Ice margin of the Pâkitsoq basin, central West Greenland. Rapp. Grønlands geol. Unders. 135, 87-95.

G. H., H. F. J. \& J. K. N., Geological Survey of Greenland, Copenhagen. 